\title{
SEEING WHAT IS NOT THERE YET: SOPHIA LYON FAHS, ENTELECHY AND THE RELIGIOUS EDUCATION ASSOCIATION ${ }^{1}$
}

\author{
Lucinda A. Nolan \\ Fordham University, Doctoral Candidate \\ Assistant Professor, Lewis University
}

\begin{abstract}
This paper offers a brief theological biography of Sophia Lyon Fahs, a religious educator whose life and work unfolded during the first seven decades of the Religious Education Association and reflected many of the identity bearing modalities that continue to give shape and continuity to the organization. In 1972, Boardman Kathan, the General Secretary of the Religious Education Association, described Fahs as "one of the truly great pioneers of religious education in the $20^{\text {th }}$ century, in the company of Harrison Elliott, Frank McMurry and George Albert Coe."2 Fahs anticipated many theological challenges to religious education that were ahead of her time. ${ }^{3}$
\end{abstract}

We are searching for new words and new thoughts. Indeed, we stand aquiver on the threshold of a new day; none sees clearly what is in the distance beyond our present experience. The possibilities are as yet untried. But there is a thrill and a glowing hope in being part of a young movement...

-Sophia Lyon Fahs ${ }^{4}$

\section{A New Century, A New Existence}

A new century tempts the historian to "construct 'watersheds' where none existed" (Hutchison 1992, 145). Apocalyptic groups calculating the end times from various starting points and sources become beehives of vatic activity. Other groups may focus on the opportunity for new beginnings and resolutions. The very atmosphere becomes one of eschatological expectation and apprehensive anticipation. Such was the climate into which the Religious Education Association emerged. The early years of the twentieth century held great promise for human progress and while history may never

\footnotetext{
${ }^{1}$ The phrase "seeing what is not there yet" and the notion of entelechy in historical method are taken from Marianne Sawicki, "Historical Methods and Religious Education," Religious Education 82:3 (Summer 1987): 375-389. Meaning and identity gradually accrue (Fiorenza) or are disclosed (Farley) in history, "pulling the entity on toward its own self-fulfillment. This amounts to a seeing of what is not there, yet, through what is already given in the past and in the present" (388-389).

${ }^{2}$ Boardman Kathan, "A Pioneer Religious Educator: Sophia Lyon Fahs at 95, an interview," UU World (February 1, 1972).

${ }^{3}$ Within the text of this paper all quotes appear as they were originally written. No attempt has been made by the author to alter the quotes for the purpose of rendering them gender inclusive. Radically inclusive in all aspects of her theology and philosophy, it is evident that Sophia Lyon Fahs was following the literary style of her time and in no way intended gender exclusivity.

${ }^{4}$ From Sophia Lyon Fahs, Today's Children and Yesterday's Heritage (Boston: Beacon Press, 1952),vii.
} 
mark the beginning of the R.E.A. as a watershed event, it was nevertheless a time of high hope and optimism for the charter group.

Theologians at the dawn of the new century sought to fill the spiritual void left by the Enlightenment by bringing Christianity into line with modern ideas and culture. Evangelical revivalism had been unable to meet the urgent needs of the urban church and its educational system had been ineffective. The liberal movement in theology was finding its public voice. William James' pragmatism and John Dewey's progressivism had captured educational and philosophical imaginations and held great interest for some of the more progressive religious leaders. Early in the new century a liberal religious group, the Senate of the Council of Seventy, felt the time was suitable for "the undertaking of a general movement toward the improvement of religious instruction in the United States (Proceedings of the First Annual Convention 1903, 297). The response to a circular letter sent out by the American Institute of Sacred Literature to determine national interest came in the form of over two hundred letters expressing "often with great earnestness, that the conditions were right for undertaking an advance movement" (Proceedings of the First Annual Convention 1903, 299).

The historical existence of the REA began in Chicago at its First Annual Convention which opened with an organ recital at 7:30 p.m. on Tuesday evening, February 10, in the year 1903. The opening prayer, given by Rev. Heman P. DeForest is telling:

We have come up here from many a quarter of this broad land, and we have not come with empty thoughts or empty hearts; we have come through the conviction of a great need that seems to stare us today in the face - a need that belongs to thy kingdom, a need the satisfaction of which means much, we believe, to the present generation and to the future (Proceedings of the First Annual Convention 1903, 3).

Addresses were given throughout the next three days by such notables as George A. Coe, John Dewey, Shailer Mathews, Frank Sanders and the first President of the REA, William R. Harper. The R.E.A., one hundred years later, at a time when organizations come and go with remarkable rapidity, is still in existence. Many of the original concerns and reasons for coming together have come and gone and come again throughout the years often resurfacing in new forms. As Stephen Schmidt noted in the introduction to $A$ History of the Religious Education Association, "Since so many of the past themes continue to engage the R.E.A., there is little doubt but that the association will continue to struggle with historical continuities and current changes" $(1983,8)$.

That the R.E.A. has returned repeatedly to similar themes throughout the century is an indication of the association's entelechy or "tendency ...toward some strands of historic possibilities and not others" (Farley 1982, 297). "Entelechy provides the principle by which we can grasp the essence of something even though it has been only partially or imperfectly manifested. The gist of an identity is discerned in the past historically, but projected toward future actualization by entelechy" (Sawicki 1987, 378- 
379). The full realization of any meaning and identity only gradually "unfolds as the entity makes impacts upon subsequent generations (Sawicki 1987, 388). A historical entity like the R.E.A. is pulled "inexorably on toward its own self-fulfillment" by its entelechaic qualities (Sawicki 1987, 389). Associations, as well as individuals, by looking to the past and closely observing the present, may make somewhat accurate assumptions about their future. "This amounts to a seeing of what is not there, yet, through what is already given in the past and in the present" (Sawicki 1987, 389).

My task is to examine the theological influences on the work of one religious educator whose life, like the Religious Education Association itself, gradually continues to unfold new meanings to new generations. Though Sophia Lyon Fahs was a single fragment of this history, her work, which spanned the first 75 years of the R.E.A., mirrors the association's history. As historian Stephen Schmidt wrote,

The R.E.A. is like a professional family of origin. There are forefathers and foremothers, rituals and traditions. There are myths, symbols, and family legends imprinted on the profession to this day. Family artifacts and documents legitimate the heirs of that family story. $(1983,2)$

Sophia Lyon Fahs's theology and philosophy of religious education give legitimacy to our professional family of origin. Moreover, her ability to see what was not there, yet, provides us with a treasured heirloom that continues to unfold new meaning for subsequent generations of religious educators.

\section{A Theology Politely Ignored}

When Shirley Ranck wrote a commemorative article for Religious Education on the occasion of Sophia Lyon Fahs's one-hundredth birthday, there were more than a few readers who were startled to find that it centered, not on Fahs's exceptional editing of religious education materials, nor on her work with children, but on the "prophetic theology" implicit in her work and writing" (Ranck 1976, 604). Only a few writers have acknowledged the distinction of Fahs's theology. These include her biographer, Edith Hunter, and Emil Gudmundson, who had written and delivered a talk entitled, "The Theology Implicit in the Writings of Mrs. Sophia Lyon Fahs" to a group of Unitarian ministers in 1956. Both Hunter and later Ranck attributed the lack of attention given to Fahs's theology to the fact that she was "a woman in a theological drama, a drama in which women were not usually given roles" and that "her consuming interest was children and religion, a combination that most theologians would prefer to avoid" (Hunter 1966, x). Fahs's emphasis on the values of freedom and change, as well as on universalism and pluralism, placed her at odds with both orthodox and neo-orthodox theology. "Her daring theological views often made her the storm center of controversy" (Beck 1978, 717).

Emil Gudmundson wrote a short summary of Fahs's theology which he put together from several sources but primarily from her major philosophical treatise, 
Today's Children and Yesterday's Heritage. He too addressed the lack of recognition for Fahs's theological thought:

The idea that Mrs. Fahs is the leading Unitarian theologian was not only new to me, but it seemed that it was because the Beacon curriculum is nontheological that it was so attractive to liberals. Mrs. Fahs's contribution has always seemed to lie in two areas: 1) in education ... and 2) in a child guidance theory which is developmental. Now it seems that Mrs. Fahs may have a third contribution to make: a theology. I have accepted the challenge to discover what it may be and have been heartened to find that indeed there is at least an implicit theology in all her writings.(Gudmundson 1956, 1)

Gudmundson continued by noting that, in his opinion, the Beacon curriculum for which Fahs served as editor, was not lacking in theology, but was of such a new theological orientation that many either had not understood it or were fearful of its possible impact on religious communities $(1956,2)$.

Further consideration of the scarcity of attention to Fahs's theology and the underlying reasons for it may be found in a later article written by Unitarian minister, Reverend Shirley Ranck:

Women today are often recognized for contributions which do not challenge basic patriarchal structures. Work with children is acceptable for a woman, as is the development of curricular materials for children and a philosophy of education for teachers and parents. A sophisticated theology which challenges the whole biblical patriarchal world-view on the basis of twentieth century science, however, is likely to be ignored, especially if it is written by someone whose main focus is children. $(1990,28-29)$

Though Fahs's theology touched on all the standard categories, it was not totally comprehensive nor was it systematically organized or presented. It lacked a strong ecclesial element and her views on the humanity of Jesus were often the center of controversy. While always operative and evolving, Fahs's theology, like that of other progressive liberal religious educators, often took on the language of education. In no way put aside, Fahs's theology became deeply embedded in her philosophy of religious education. Fahs explained to doctoral candidate David Parke:

I would not say ... that my interest was primarily in method, or that it was not theological. Even in those beginning days of my teaching experiences, I felt keenly that the children's theological beliefs and mine were very much involved. Theology meant then, as it does now to me, a way of interpreting existence to meet one's own personal need for a guiding philosophy. (Fahs 1962, 296-297)

Parke, who interviewed Fahs on several occasions for his dissertation, asked Fahs to characterize her theology. She responded: 
I guess my theology is more homemade. I had to struggle. I made a synthesis of what I got from many. I was never satisfied with just one. My thinking was in flux all the time. Nobody I followed taught me what to teach. I thought sometimes that I was following a lonely road. The theologians didn't see things from the viewpoint of children. Educators didn't sense the theological issues. (Fahs 1962, 291)

Fahs's feelings of alienation from the fields of both theology and education may have led to her commitment to religious education. In the context of her life situation, her theology became embedded in her philosophy of religious education and vice versa.

Parke demonstrated in his study that theology in the classical dogmatic sense played little role in Fahs's understanding of natural religion because of her belief that each person must construct his or her own worldview and "in some measure be a theologian" (Fahs 1952a, 96). Fahs felt that theology must be continually reconstructed according to new experiences and current knowledge available from all disciplines. Without such adaptation, theology would become stagnant. Reconstructive theology, grounded in critical engagement with culture and tradition, is carried forth today by postmodern revisionists. According to Fahs, a personally constructed theology, a life long responsibility for every person seeking religious maturity, was to be formed out of his or her own experiences.

Sophia Lyon Fahs's theology was in line with the classic Protestant liberal theology of her time. However, as it evolved, her theology became more and more universal in character and eventually transcended any particular Christian tradition. Little would distract her from her liberal tendencies along the way, though her life was lived out "against the changing backdrop of [several] theological periods of which [she] was a product, an observer, a participant, and to some extent, a creator (Hunter 1966a, ix).

\section{Evangelical Theology and Missionary Enthusiasm: It Takes More Than Angels ${ }^{5}$ (1880-1905)}

In 1901, as the historical existence of the Religious Education Association was in its initial planning stages, a young woman was in the process of enrolling in courses at the University of Chicago. Sophia Lyon elected to take one class in Old Testament with William Rainey Harper and another in New Testament with Ernest DeWitt Burton. Young Sophia Lyon, a devout Presbyterian daughter of missionaries to China, was not unaware of the liberal reputation of this still relatively young university. She had been hesitant to attend the large divinity school and wrote of her concern to her fiancé: "Many skeptics are sent out of there who were formerly professing Christians. They, however, had not found, I believe, the real fundamental principle of the Christian life" (Hunter 1966a, 44).

\footnotetext{
${ }^{5}$ The phrase, "It takes more than angels," is taken from a poem by Sophia Lyon Fahs, "Our Wondering Questions" in Beginnings of Earth and Sky (Boston: Beacon Press, 1937), 153.
} 
After an introduction to the then new higher criticism as applied to biblical scholarship, Sophia Lyon found herself rethinking much of the evangelical theology she had accepted without question from her family. She later wrote in Religious Education:

Some of us who have been granted length of days can recall the exhilaration we experienced when the early findings of the higher critical research on the Bible transformed an other-worldly divine revelation into a collection of dramatic records portraying natural experiences of human beings like ourselves. (Fahs 1960a, 171)

Historical criticism would arguably become the bulwark of liberal theology for both Fahs and the Religious Education Association whose earliest concerns were for promoting "the knowledge of the Word of God as interpreted in the best light of today" (Proceedings of the First Annual Convention 1903, 297). ${ }^{6}$ Scripture and Sunday School were core concerns for the R.E.A. and would later become central for Fahs's life work.

No doubt, there were familial concerns for young "Sophie "Lyon's evangelical faith in light of her intellectual curiosity. Hers was a rigid evangelical upbringing. She recalled her childhood in a sermon: "My mother was strict about our religious life. We spent most of Sunday in church, and the rest of the day reading religious pamphlets. We were not allowed to play or even to write letters on Sunday" (Fahs 1976, 1). Fahs further described her home environment in an interview with David Parke:

We had family prayers and Bible reading every day. Each of us took our turn until we went right through the Bible. Sunday was a very carefully observed day, spent mostly going to church, reading religious books, playing Bible games and singing. I had been a faithful Sunday School pupil all through childhood. The religion of the home was serious, devout, sturdy and sincere. The beliefs were orthodox without being fanatical. I had accepted the (old) story of salvation wholeheartedly. (Fahs 1962, 249)

The missionary zeal and theological orthodoxy that led Sophia Lyon's parents to China became exemplary motivational forces for her as well. The strong sense of nationalism and the intensity of her parents' sacrifice did not go unnoticed by young Sophia. She too longed for the missionary life.

The Student Volunteer Movement afforded Sophia Lyon the opportunity to witness to her faith publicly and to meet her future husband, Charles Harvey Fahs, who also hoped to go into the field as a missionary. The Methodists hired Fahs as editor of all

\footnotetext{
${ }^{6}$ The full quote from which this phrase is drawn is taken from a chapter entitled "The Inception of the Movement." The earliest Declaration of Principles read: "The Council [of Seventy] does not stand for any theory of interpretation or school of criticism, or denomination, but for a definite endeavor to promote the knowledge of the Word of God as interpreted in the best light of today. From this point of view also the contributions of other religious literatures are sought by the Council, that through the study of these literatures the teachings of Scriptures may be more clearly understood." See, Proceedings of the First Annual Convention, Chicago: The Religious Education Association, 1903), 297.
} 
their literature on the missions and sent the newly wedded couple to New York. Sophie wrote her parents in China, "When the possibility of this being Harvey's life work came over us, it almost tore my soul in twain" (Hunter 1966a, 49). Though she became a Methodist in order to attend church with her husband, she took with her an abiding love for sharing her faith and religious ideas with others as well as her steadfast and untiring work ethic.

In 1902, Sophia Lyon Fahs directed her energies toward earning a master's degree in elementary education at Teachers College of Columbia University. There she was influenced by Dr. Frank McMurry who introduced her to the ideas of John Dewey and the religious education movement. Even though Fahs became acquainted with Dewey's progressive ideas, her thesis on missionary biography as a way of introducing biblical themes to children was written from the "vantage point of evangelical Christianity." Edith Hunter wrote:

Exactly what brought Mrs. Fahs to her unorthodox position from an orthodox Christian background, I'm not sure. Probably to a great extent it was her willingness to listen. She listened to the giants of the progressive education movement in America at the beginning of the century, and she listened to children as they talked to one another and as they were being taught the revealed truths of orthodoxy. (Hunter 1966b, 8-9)

Hunter also noted with interest a remarkable similarity of evangelical backgrounds:

John D. Rockefeller, Jr., born in 1874; Sophia Lyon Fahs, born in 1876; and Harry Emerson Fosdick, born in 1878, were all children of devout Christian homes. In their youth, living at the peak of an evangelical Christianity that expressed itself as an enthusiasm for the missionary movement, all three young people stood out as Christian idealists. ... [E] ach of them had reformulated his evangelical Christian faith in the light of his own experience in a rapidly changing world. All three had accepted the development of Modernism and the Social Gospel. (Hunter 1966a, 165)

The missionary movement and her evangelical upbringing had a lasting effect on Sophia Fahs. She was anxious to be involved with missionary work and felt that "the church [was] trifling with the work of evangelizing the world" (Hunter 1966a, 37). The energy and idealism of the period and a total commitment of energies toward working for the transformation of the world would not subside in her length of days. Though three of her siblings became missionaries, in later years Fahs would become critical of the exclusive claims of Christian supremacy in missionary tactics.

According to historian George Marsden, on the exterior, revivalism, evangelicalism and the foreign missionary movement seemed to herald a golden age of Christian ideals, but underneath, in the early years of the twentieth century, were the stirrings of intellectual and social currents that could not be held back by a value system held primarily by white, middle-class Americans (Marsden 1991, 9-16). Some of these 
intellectual and social currents that inspired the founding of the Religious Education Association at this time included new insights from psychology, modern practices of pedagogy, findings of critical and historical scholarship as applied to the Bible, and the understanding religious education and nurture as a task of all the institutions of society (school, home, church, youth societies, the press, colleges and universities) (Wornom n.d., 5). Such intellectual and social currents were nowhere any stronger than they were in New York City at the turn of the century. It was there that Fahs would come into contact with the liberal progressive ideas that were finding their voice in the R.E.A. under the leadership of William Rainey Harper and George Albert Coe. It would take more than angels to satisfy the religious imagination of Sophia Lyon Fahs.

\section{Progressive Liberal Theology: Dewey + Coe=The Democracy of God (1905-1930)}

The liberal theology that emerged in the late nineteenth and early twentieth centuries was an attempt to reconcile Christianity with "modern commitment to the values of free and open inquiry, autonomous judgment, [and] critical investigation of all claims to scientific, historical, philosophical, and religious truth" (Tracy 1975, 25-26). "Theological liberalism was dominant in the origins of the religious education movement in Protestantism. The pioneers in this movement, George Coe, Sophia Fahs, and Harrison Elliot, were greatly influenced by the progressive educational theory of John Dewey" (Elias 1986, 41). Coe, adapting Dewey's theory of education as the reconstruction of experience for the transformation of society, wrote of the role of religious education in establishing the "democracy of God".

For Sophia Lyon Fahs, Dewey's philosophy became the centralizing force for her own theories of religious education. As with George A. Coe, her theology became colored by Dewey's thought as well as by emerging liberal ideas. Her earliest recollections of her transition are from her undergraduate days at the College of Wooster emerged in her interview with Parke:

In college I could go to evangelistic meetings and weep my head off, but even then something bothered me about the idea of Jesus as savior. . . I I began to sense a certain degree of insincerity in the songs we sang. . . .I began to question if Jesus saved us, why bother to be good? Somehow the incentive for any significant living was missing. (Fahs 1962, 249-250)

During her college years Sophia Lyon read Charles M. Sheldon's In His Steps: What Would Jesus Do? and came under the tutelage of her brother-in-law, Henry B. Sharman who had earned a Ph.D. in New Testament from the University of Chicago Divinity School. She became acquainted with the idea of Jesus as a historical figure who left an ethical legacy for humankind to follow. These ideas began a reformation in the theological thought of young Sophie Lyon.

The reformation of Sophia Lyon Fahs's theology continued at Teachers College as she sought to further prepare herself for what she hoped was an immanent call to the 
mission field. While Fahs's theology remained firmly evangelical, the work of John Dewey, as taught to her by Professor Frank McMurry, fascinated and motivated the young woman to pursue the study of the religious education of children. She later remarked concerning this time, "Little did I dream that someday I would be a member of his [Dewey's] ultra liberal denomination" (Fahs 1976, 2). She recalled:

I was a religiously motivated woman, yet with no understanding of the educational philosophy with which John Dewey's name was already so vitally related, nor had I acquired during my undergraduate work any special interest in children. ... John Dewey's dynamic propositions were not simply congenial to my own thinking, they motivated me to pursue their implications in the total process of learning how to live valuably (religiously) in the natural world. They also impelled me to test their potentials and to raise devastating questions regarding the common ways of seeking the religious development of children. (Fahs 1965b, 3)

Her theology absorbed Dewey's philosophy as it did the thought of others like George Albert Coe, though she would claim no one as a primary source of her theory, practice or theology. In reference to her years at Teachers College and later at Union Theological Seminary she said to David Parke:

There was a constellation of ideas, influential for the last sixty years, that was influential [for me]. It's been a privilege to be a part of it, in books, the interchange of ideas. I was a contemporary of many of these people; we could talk back and forth ... [but] I've been enough of a rebel not to be a disciple of any of them. (Fahs 1962, 298)

Liberal theology attracted Fahs and once it did, it took hold of her imagination and never let go. This was the theology that was behind the founding of the Religious Education Association and it was the theology that would color Fahs's philosophy of religious education. Reactions against the "uneducational" evangelical techniques for the transmission of faith, the necessity of emotional conversion experiences, and the literal interpretation of scripture were strong in the liberal theology of the religious education movement.

After completing her graduate education at Teachers College, Fahs took some years to raise her family, but kept up with her profession and its literature and when the opportunity arose for her to study religious education at Union Theological Seminary, she jumped at the chance to "be on equal standing with the pastor in the church" (Hunter 1965a, 130). Liberal theology marked by modernism was vibrant and alive at the Seminary as was the new religious education. Fahs was more than likely attracted by the experimental Union School of Religion that had superseded the Sunday School at Teachers College where she had previously taught (Hunter 1966a, 133).

Fahs's years at Union Theological Seminary (1923-1926) coincided with the height of progressive modernism and liberal theology. It was an exciting time for Fahs 
who was ready to devote herself fulltime to the new philosophy of the religious education movement, which in the 1920s was still enjoying a large following. The effects of World War I and the new crisis theology that was challenging the optimism of liberal Protestant theology would not be felt in religious education until the 1930s (Schmidt 1983, 74). Union Theological Seminary was a hotbed of modernist thought and Sophia Lyon Fahs became enthralled by it all. George Albert Coe, formative theorist of progressive, liberal religious education who had originally developed the courses in religious education for theological students, had recently left the faculty of Union Theological seminary. Edith Hunter wrote of his theological position:

For several years, progressive religious educators had been feeling increasing tension between the naturalistic philosophy presupposed by the methods of the progressive secular educators and the content of even a liberal evangelical Christian faith. Men like Coe and Hartshorne were being forced to decide whether their purpose in religious education was the transmission of the Christian heritage or the guidance of individuals and groups in a process of creative growth. These two men chose to interpret it increasingly in terms of creative growth. (Hunter 1966a, 145)

At Union, Fahs studied with many great teachers of theology, church history and religious education. "The professor at Union... who had the most influence on me was Dr. Arthur C. McGiffert; I took as many courses from him as I could; . . . [He] gave me a background, especially in the history of Christian thought" (Fahs 1962, 271). In her discussion with Parke, Fahs added that her "knowledge of Christianity was influenced by my theological professors; my theological thinking was more influenced by people outside of the field of theology that by those within" (Fahs 1962, 271). Her B.D. thesis at Union Theological Seminary, "Certain Problems Involved in Building a Curriculum in Religious Education," reflected her newly formulated progressive liberal ideas. Concerning the use of the Bible in religious education Fahs wrote:

Our fundamental position is that how to live a good life is a problem not a precept, that religion and morals call for a creative striving and searching. Such a position prevents our going to the Bible or to any historical material to find an authoritative guide, or to learn a divinely given law to be obeyed....

We are thinking of the Bible as one source book among others containing stories of very real human experiences with some of these very vital problems which the child is facing today. (Fahs 1926a, 51-52)

Union Theological Seminary supported the basic tenets of the Social Gospel Movement during Fahs's years of study. Hunter wrote of these years at Union: "If the first two persons of the demonic trinity enthroned at Union Theological Seminary, as far as the Fundamentalists were concerned, were Modernism and the Social Gospel, the third person was the new religious education" (Hunter 1966a, 157-158). Already a follower of the historical emphasis on the humanity of Jesus, Fahs saw the social and moral imperatives of Jesus' teachings as the basis of her understanding of the gospel message. Like the movement's founder, Walter Rauschenbusch, Fahs thought the Kingdom of God 
of which Jesus spoke was of this world and to follow Jesus meant to act for its social reconstruction. Fahs wrote of the social Gospel and its way of idealism:

The vigorous preachers of the "social gospel," especially honored during the first three decades of our century, encouraged the churches to participate in significant social reforms. The teachings of Jesus were seriously examined and held up for emulation. By shifting the center of interest from doctrine to social action, these socially minded prophets led the churches to feel that it was more important to struggle to make society more Christian than it was to struggle to reform the traditional theologies. ${ }^{7}$ (Fahs 1955, 180)

Fahs's distinct and identifiable theology was first formed in the tradition of evangelical Protestantism. Over the years, her probing questions, pragmatic doubts and liberal higher education led her to a liberal theology void of the metaphysical and overly theological language of doctrinal theology. Her theological views were formed and transformed by the times and situations in which she lived. By the year 1928, this theology was challenged by new developments at Union Theological Seminary.

\section{Neo-orthodox Theology: Reinhold Niebuhr and the "Neo-ancient" Interpretation of Scripture (1930-1955)}

By 1926, Sophia Fahs had earned a Bachelor of Divinity degree from Union Theological Seminary. She was offered the position of principal at the prestigious experimental Union School of Religion and a year later became one of the first two women (the other was Adelaide Case) to lecture at Union Theological Seminary. In the fall of 1926, Henry Sloane Coffin became President of Union Theological Seminary and invited a young, liberal social gospel preacher to join the faculty. The young man's name was Reinhold Niebuhr. By the end of the decade dramatic changes in Protestant theological thought were becoming evident. World War I, the stock market crash of 1929 and the Great Depression left the country in need of a theology of crisis. Edith Hunter wrote of this period:

The spirit of optimism that so often accompanied the efforts of the advocates of liberal Social Gospel was sadly inappropriate to the times. ... The economic depression and an increasingly ominous threat of social and international discord provided the abyss and Union Theological Seminary was providing the seedbed of an alternative theology. (Hunter 1966a, 168)

The alternative theology was neo-orthodoxy and Reinhold Niebuhr, along with Paul Tillich, became its leading spokesperson in the United States. Neo-orthodox theology

\footnotetext{
${ }^{7}$ Though she was a strong advocate of social transformation as the goal of religious education, the reformulation of traditional theologies was Fahs's main agenda. See her The Old Story of Salvation (Boston: Beacon Press, 1955), 180 ff. for more on her views of the social gospel movement.

${ }^{8}$ Fahs used this expression to refer to neo-orthodox theology in a response to Angus MacLean's "The Theological Dilemma in Religious Education," Religious Education 55 (Jan./Dec. 1960): 173.
} 
sought to redefine the truth of Christian salvation history - a story that Fahs and other liberal theologians had come to see as so deeply historically conditioned that it could no longer contain the scope of what they considered God's plan for the salvation of a world community. The new theology saw the Social Gospel message and liberal theology as naïve and powerless in the face of the desperate situation of the world. Niebuhr "developed an almost cynical realism that never tired of observing the twin facts that good men are not as good as they think they are or appear to be, and that our social order is far more unjust than it appears on the surface to be, especially to those who hold a comfortable place in it" (Hunter 1966a, 169).

Fahs was never swayed by neo-orthodox theology. To observers it seemed that she was aloof to the theological storms going on about her. In speaking with David Parke, Carl H. Voss recalled his observations of Fahs while he was at student at Union Theological Seminary in the mid 1930s:

Mrs. Fahs seemed remote from the intellectual maelstrom in theology which had been precipitated by the appointment of Reinhold Niebuhr. . . . She appeared bewildered, even startled, by the swirling currents of thought at Union, and seemed to regard the controversies over Karl Barth, Emil Brunner, and Rudolf Bultmann as taking place in another world quite foreign to her own. (Voss 1964, 285)

But these observations were not quite accurate. Fahs was well aware of what was going on, and if she was bewildered it was over the question of how it was that so many "theologians and biblical scholars are the ones who are taking the lead in this continued loyalty to tradition" (Fahs 1960a, 173). She felt it was a return to the evangelicalism of her childhood that she had long since outgrown. Edith Hunter saw the theological conflict between Fahs and Niebuhr as the result of their unwillingness to listen to each other and of being too quick to judge each other's positions. ${ }^{9}$

Whatever Fahs was, she was not aloof to the challenges presented by what she called "the new-old stereotype of Biblical theology" (Fahs 1960a, 171). In 1945 at a meeting with other liberal religious educators at Bourne Hall in Yonkers New York, Fahs decried the detrimental effects of the new theology on religious education. As recording secretary she wrote of the theologies' marked differences in the areas of human nature, good and evil, the supernatural and natural, Biblical interpretation and historical criticism, revelation, judgment, tragedy, and individual responsibility. Under Topic II, "The Neo-Orthodox Movement and Its Significance," the liberal group attempted to ask self-critical questions in light of the neo-orthodox critique. "Do we seek God too

\footnotetext{
${ }^{9}$ See Hunter's Sophia Lyon Fahs: A Biography, 179-181. Niebuhr referred to Fahs in his Leaves From the Notebook of a Tame Cynic (San Francisco: Harper \& Row, 1929), 127, as a "delightful little expert" who advocated that "we ought not really teach our children about God lest we rob them of the opportunity of making their own discovery of God, and lest we corrupt their young minds by our own superstitions." Apparently, Niebuhr heard Fahs speak at a conference of the Religious Education Association which he considered "the last word in absurdity." Hunter felt he had overstated Fahs's position and posited that Niebuhr knew little about children. Had he take the time to understand Fahs's position, Hunter felt Niebuhr would have found that they were not so far apart in values after all.
} 
exclusively in the good and beautiful? Have liberal evaded a realistic looking at evil? Is tragedy really at the heart of life? (Fahs 1945b, 3-6).

Fahs's strong sense of the universality of God's revelation within the various religious traditions of humankind and her inability to assent to any sort of overt supernaturalism left her at extreme odds with neo-orthodoxy. Jesus as one savior among many and the Bible as one sacred text among others were notions she would never compromise.

"By the end of the thirties and the beginning of the forties voices were being raised by religious educators who had adopted the New Orthodoxy" (Hunter 1966a, 205). Fahs wrote of these times in notes to her biographer, Edith Hunter:

[The] neo-orthodoxies of Niebuhr and Tillich did not affect my teaching much until after the Union School of Religion had been given up, and I was on the faculty teaching theologies. My last year in the Union School of Religion was Niebuhr's first at the Seminary; and Tillich did not enter the picture until 1933. In fact, I think the Neo-orthodox Movement amazed me more than it handicapped me at the time. I could not bring myself to think that Biblical scholars had really gone back on the findings of Higher criticism and archaeology so completely... (Fahs 1965a, 5)

In 1947 a report submitted to the International Council of Religious Education by a largely neo-orthodox committee stated: "Man left to himself does not find salvation." Fahs, who was asked to comment on the report, responded:

(One wonders, when is a man ever left to himself? And what sort of salvation does he fail to find?) ... On the one hand, the report insists that the very spirit of Protestantism depends on "the vision and energy of free spirits." Yet, at another part of the report, it is insisted that these so-called free spirits "must work within the framework of the historic Christian tradition." (Fahs 1947, 4-5)

Fahs thought the report was riddled with ambiguity. She felt it tried to portray a false sense of harmony among liberal and neo-orthodox theologies. In the same report she wrote:

Inconsistencies, revealing unresolved conflicts, lie buried throughout the report. The apparent unanimity has been secured by using vague and stereotyped phrases, capable of differing interpretations, and by guarded statements from which have been deleted those parts that might have clearly revealed the differences.

(Fahs 1947, 3)

In 1952, Fahs wrote an open letter to the presidents of several liberal theological seminaries expressing her concern over the dominance of neo-orthodox thought and what she thought might be done in the seminaries to bolster the liberal agenda. She could not or would not see that the liberal enterprise had lost its persuasiveness. The letter stated: 
The growing strength of a counter movement to protect traditional religion is a serious threat to liberal advance. The growth of neo-orthodoxy with its desperate attempt to salvage "the faith of our fathers;" the widespread effort to strengthen ecclesiasticism by making it worldwide and by clinching it together by the creed; the repeated proclaiming of the supremacy of the Christian religion; the revived emphasis on ecumenism, seen in terms of establishing a world society of believers in the Christian gospel and way of life; all these are signals pointing to the widening cleavage between freedom and indoctrination in religion. ... Our liberal movement is in danger of being blurred out by the hidden evasions and mystifying language of this group of pseudo-liberals. (Fahs 1952b, 1)

Fahs's reaction to neo-orthodoxy was not unlike the response of the Religious Education Association to the new theology, though the case may be made that she was more open to the possibility that the neo-orthodox critique of liberalism may be, in some areas, correct. Schmidt referred to the 1935-1952 era as an "Old Response For a New Situation" $(1983,107)$. He wrote:

The most encompassing irony of the era seems to have been the inability of the aging liberals to be open to the center of the liberal creed, that is, open to the possibility of change. . . They chose R.E.A. orthodoxy over emerging new theologies. They seemed to live in a past period, repeating old slogans, even though the world was struggling with a new metaphor for reality and the presence of the ancient symbol so experientially validated, called sin. (Schmidt 1983, 109)

Fahs saw the new theology as narrow, exclusive, and guilty of not using the widening body of religious knowledge adequately. She wrote in Religious Education:

How has this continued narrowing of the content of religious education in our churches been possible in spite of our generation's greatly expanded knowledge of man's religious history? Simply stated, this has been done by removing the Christian historical heritage from the field of natural observation, inquiry and reasonable thought, unless the study reveals the biblical events "as the redemptive activity of God." (Fahs 1960a, 172.)

Fahs's remaining years at The Union School of Religion (1924-1929) and Union Theological seminary (1926-1944) were spent pursuing her increasing liberal insights into religion and religious education. In 1933, a few years after the Union School of Religion closed, she became affiliated with the liberal pulpit of Harry Emerson Fosdick at Riverside Church as a faculty member. She continued to work experimentally with her evolving ideas about the religious education of children. From 1937 until 1964 she was editor of the Unitarian New Beacon Series in Religious Education for juniors for which she received international recognition. 
"The controversy that divided the theological world and Union Seminary into warring factions in the late thirties and early forties somehow left Sophia Fahs unperturbed. The task she had set for herself many years before was to help children build an adequate religion for themselves, and to tell them the story of man's long search for religious understanding" (Hunter 1966a, 207). Were she here today, her task would assuredly remain unchanged.

\section{Seeing What Is Not There Yet: The Theological Legacy of Sophia Lyon Fahs}

There is much in the theology of Sophia Lyon Fahs to be reclaimed by this subsequent generation. The effects and potentialities of her work are greater than those realized in her lifetime. There continues to be a living out of original ideas and originating purposes of the Religious Education Association though they are remembered and packaged in new bundles in new eras. The ideas and purposes that have survived in the community of the R.E.A. are those elements that have remained important to its identity. Every pioneering member and every historical twist and turn become important in our understanding of who we are and where we are going.

This theological biography of Sophia Lyon Fahs has focused on the years of her closest association with the R.E.A.. Ironically, she increasingly felt "ideologically unwelcome" ${ }^{10}$ in the association as it took more seriously the originating call to inclusiveness. Liberals were simply ideologically becoming unwelcome in most places. However, The Religious Education Association and its journal continued to honor her efforts in the field on the occasions of her special birthdays and with commemorative articles after her death at the age of one hundred and one in 1978.

The legacy of her work can hardly be given justice here, but her remarkable foresight concerning many prominent contemporary issues should be noted. By keeping her finger on the pulse of her times and by a deep and conscientious examination of her own experiences as well as those of others she was able to see with remarkable clarity what was not there yet. Seven visionary aspects of Fahs's thought will be briefly addressed.

Firstly, Fahs sensed an immanent danger of the church losing its young members due to a conflict of methods used in religious education and science. She wrote extensively on the need to harmonize the findings and processes of science with religious teachings. As early as 1928, in a paper she delivered to the Religious Education Association, Fahs wrote:

The deductive process in religion has been clashing with the inductive

\footnotetext{
${ }^{10}$ This phrase was used by Fahs in a letter to Herman Wornom written in 1957 about her concern for the increasing feeling of alienation among progressive and free-thinking liberals in the R.E.A.. (Unpublished letters, Wornom Years Files (Feb. 1, 1957), The Archives of the Religious Education Association, Yale Divinity Library Special Collections, New Haven, CT. On the same subject, Stephen A. Schmidt quoted Ernest Chave as saying in 1950, "It is a lonely and discouraging experience to be a liberal without friends," and Harrison Elliott in the same year, "For many, because of certain theological developments in recent years and because of attacks upon religious education, there is a feeling of isolation. For them the association furnishes a rare fellowship." See Schmidt, A History of the Religious Education Association (Birmingham, Alabama: Religious Education Press, 1983), 107.
} 
process in science. This fundamental conflict between the two types of processes, and the efforts of religion to turn about face and to travel with science are fraught with so great significance for religious education and for religion itself, that if we could visualize what it is that is coming to be, we would speak as it were with tongues of fire. (Fahs 1928, 1)

Years later in her delivery of the Rufus Jones Lecture Fahs spoke of foreseeing "young people rejecting religion in increasing numbers" and "the moral foundations of our society crumbling" if religious groups did not "learn how to inject therapeutic understanding for the old judgmental and moralistic ways of religious training" (Fahs 1960b, 19).

Secondly, Sophia Lyon Fahs foresaw problems arising from an outmoded biblical cosmology and sought to reconstruct her own theology on the basis of the latest scientific views on the nature of the universe. She devoted an entire chapter in her treatise on her philosophy of religious education to the topic:

To build the beginnings of faith in God on a conception of the universe that our generation no longer regards as true is to prepare the way for a loss of respect for the Bible; and what is worse, to court a cynical atheism when the child is old enough to learn for himself. (Fahs 1952a, 106)

The topic is later treated in an article by Shirley Ranck that noted three aspects of biblical cosmology that seemed especially troublesome to Fahs. Those were: 1) the idea that creation was completed in the past; 2 ) the dualism established between the natural and the spiritual worlds that clearly elevated the latter over the former; and 3) the idea that the cosmos is controlled by a God who "uses the forces of nature as a means of moral discipline" (Ranck 1990, 34-35).

A third foresight was the enduring call of Fahs to church leaders and religious educators for the need to be both courageous and adventurous in the work of reconstructing traditional religious symbols and myths for modern times. "The way of searching for new and truer insights ... is a way that calls for a courageous, creative adventure, involving much sharing of knowledge and experience" (Fahs 1955, 186). "There is fear lest, in improving the structure, the foundations may be blasted. Emotional tensions run high. ... Everyone, in a measure, must be a theologian" (Fahs, 1952a, 96).

A fourth concern of Fahs's and a timely topic for today's religious education is religious pluralism. Fahs believed that from the youngest years and throughout life, the study of the religions of humankind not only enhanced the understanding of one's own religion but also led to a greater sense of connectedness among all people. The world community, she felt, must seek to understand and accept various religious traditions as validation of humankind's common search for the divine in diverse but life-enhancing ways.

Our common living room is now the whole earth. Whether we will or no, our 
neighbors are on the other side of the globe as well as next door. In the light of this spaciousness in our exchanges, we find it unseemly to imagine ourselves superior. The realities of our shortcomings are all too easily observed by other nations and groups. Nor can we arrogate to ourselves an exclusive religious revelation. The Scriptures of other religions are easily accessible to every scholar. Any one group today that tries to dominate the whole world by its ideology or by military might, or by force of any kind, will eventually win only the hatred of those who are put under its power. (Fahs 1952a, 150)

Not only does such a broadening of perspective open the possibility for world community, it deepens the appreciation of one's own religious tradition and beliefs. In a chapter entitled, "What Shall Children Study?" Fahs wrote:

Modern youth growing up in our modern world needs to find much more understanding of the world's religious history than has been allowed to any previous generation. .... Indeed, the values in one's own religious heritage can never be understood or fairly appraised until one is able to compare his own with others. (Fahs 1952a, 184)

A fifth and profoundly prophetic insight of Sophia Lyon Fahs concerns the need for a creation theology. Fahs deep respect and love for the natural world is reflective of her belief in God's immanence and the revelatory capacity of the universe. The study and appreciation of nature were emphasized in religious education curricula written and/or edited by Fahs. In A New Ministry to Children she wrote:

The Universe has been struggling through a long evolution. We are the fruits of her millions of years of labor. Our flesh is the evolved dust of the stars.

Our very life is dependent upon the continuing life and death of other creatures. Without the common green world of grasses and grains we should quickly perish.

Our indebtedness is a heritage that links us to all living and nonliving things from the beginning of time.

The Living Universe does not ask us to accept things as they are. She challenges us to join in creating better things. She asks us to help her improve.

In our pride of human superiority, we have sometimes been disdainful of the values in things of a so-called lower order.

We have talked of subduing the forces of nature to serve our ends.

The Living Universe calls us to understand, to appreciate, to cooperate-rather than to conquer.

An exclusively human ethic is narrow. (Fahs 1945a, 7)

A sixth foresight was voiced by Fahs at her ordination and echoed over the years in many of her writings including her last article for Religious Education, written when she was ninety-five years old. It was a life-long effort of hers to improve the quality of 
religious education for the young. The field of religious education, she felt, must seek the brightest and best of young teachers and professionally prepare them, along with the ministers, to nurture the religious sensibilities of children. Fahs believed "that all theological seminaries and institutions for the development of religious leadership must give more attention to children" (Fahs 1971, 458-459). She continued:

I believe that during the past as well as today Christian churches have been neglecting the children, even though Sunday Schools have been growing in size and equipment; and few theological seminaries give the education of the ministers to children their whole-hearted interest and respect. ... At present it takes a very strong purpose and a willingness to sacrifice prestige for a man or a woman to enter the field of the religious education of the young. Ministers in preparation should be helped to feel more keenly the critical importance of the children. (Fahs 1971, 458)

Fahs understood the task of her vocation as "reconstructing the processes and the content of the religious education of children in light of mankind's growing understandings" (Fahs 1971, 458).

One final example of Fahs's ability to see what was not there, yet, is evident in the very way she chose to live out her life and to make decisions along the way as a woman of rare confidence in a field occupied predominately by men. She felt before she married that she wanted to do some great work for God. While she thoroughly enjoyed her childraising years ("The children were my teachers.") she openly confessed her ambitions to her husband. At times the demands of home life kept her from writing as much as she would like. Her youngest daughter Lois Fahs Timmins recalled:

My mother was an early feminist and wrote an article on Women's Suffrage before I was born. . . . Our household chores were not assigned according to sex, but according to our interests and capabilities. ...

Mother fought all her life for equal rights for women. She complained that at Union Theological Seminary the women instructors were paid less than the men instructors, and was almost fired for her protest. . . .

Our family deity was not sex-linked. . . . Today, I have little enthusiasm for the arguments as to whether God is male or female. (Timmins n.d.)

Fahs would not have identified herself as a feminist nor was she was involved in specifically feminist causes or organizations. However, she was determined to both raise a family and have a professional career. Fahs was "aware of being part of this 'new Age of Women' and she took for granted her right to a higher education and a career" (Ranck 1990, 29). Fahs wrote of her feelings:

I am too ambitious to serve the women of some heathen land, to be a nonentity for the direct work of foreign missions that some wives seem to be. I am too ambitious to give my life in direct foreign missionary work, to give twenty 
years of the strength of my life in service at home as my mother has done. Such lives count a great deal, but I long of the other. (Hunter 1966a, 42)

In A Feminist Look at the Theology of Sophia Lyon Fahs, Shirley Ranck wrote: "Fahs saw that the authoritarian structures that pervade our society and dominate our thinking are rooted in biblical cosmology and morality" (Ranck 1990, 32). "[It] is striking that a woman theologian, simply by trusting her own judgment and experience, developed a theology which is in many ways a radical challenge to patriarchal religion" (Ranck 1990, 40).

\section{Conclusion}

In looking at the historical fragment of this short theological biography of Sophia Lyon Fahs, it is possible to glimpse some of the historical portraiture ${ }^{11}$ of the corresponding years of the Religious Education Association. Both the woman and the association were concerned with the principal values of Scripture, religious and moral education as broad ecclesial and public concerns, the necessity of correlating religious tradition with contemporary experiences and knowledge from all disciplines, appreciation for the all the religions of humankind, and a radical sense of inclusiveness with the hope for a future unity of all people of the world. These ideals remain at the heart of religious education and constitute the potentialities of the entelechy of both Fahs and the R.E.A. to be realized anew in increasingly diverse ways with each new generation. Stephen Schmidt ended his history with a quote from John Westerhoff: "Another uniqueness of the R.E.A. is its commitment to the religious and moral education of the public, and hence an historic willingness to engage in painful dialogue around the most volatile issues related to that end. That potential is yet to be realized" (Schmidt 1983, 192). Sophia Lyon Fahs would agree. For her, painful dialogue and imponderable questions were lures into the realm of growth, learning, religious maturity and a life well-lived.

\footnotetext{
${ }^{11}$ Edward Farley used this term as a metaphor for a multidimensional historical survey that includes not only the study of origins, but transitions, crises, responses, and interpretation as well. See Farley's Ecclesial Reflection 1982, 298).
} 


\section{References}

Beck, Dorothy Fahs. 1978. Sophia Lyon Fahs: Militant liberal and lover of children. Religious Education 73(6): 714-720.

Elias, John L. 1986. Studies in theology and education. Malabar, Florida: Krieger Publishing Company.

Fahs, Sophia Lyon. 1926a. Certain problems involved in building a curriculum in religious education. B.D. Thesis, Union Theological Seminary, New York. 1926b. Has the missionary movement promoted world-mindedness at home? Religious Education 21 (April):172-178.

. 1928. Changes necessary in elementary religious education due to conflicts

between science and religion. Religious Education 24 (Dec.): 332-338. . 1937. Our wondering questions. Beginnings of earth and sky. Boston:

Beacon Press.

. 1945a. A new ministry to children. Boston: American Unitarian Association. 1945b. The report of the Bourne hall workshop. Sophia Lyon Fahs Papers,

Andover-Harvard Theological Library, Harvard Divinity School. . 1947. A discussion on the report of the committee on theological and educational foundations presented to the I.C.R.E. Sophia Lyon Fahs Papers, Andover-Harvard Theological Library, Harvard Divinity School. . 1952a. Today's children and yesterday's heritage. Boston: Beacon Press. . 1952b. Open letter to Eliot, MacLean, Robbins, Ratcliff. Sophia Lyon

Fahs Papers, Andover-Theological Library, Harvard Divinity School. . 1955. The old story of salvation. Boston: Beacon Press. . 1960a. Comments. Religious Education 55 (Jan./Dec.): 171-173. 1960b. Why teach religion in an age of science? The Religious Education

Committee of the Friends General Conference. . 1962-64. Interviews with David Parke. The historical and religious antecedents of the New Beacon Series in religious education. Ph.D. diss., Boston University. 1965a. Notes to Edith Hunter on Fahs's biography. Sophia Lyon Fahs

Papers, Andover-Harvard Theological Library, Harvard Divinity School. . 1965b. Some grateful memories of John Dewey. Sophia Lyon Fahs

Papers, Andover-Harvard Theological Library, Harvard Divinity School. . 1965c. Worshipping together with questioning minds. Boston: Beacon Press. 1971. The future and religious education. Religious Education 66

(Nov./Dec.): 457-459. . 1976. Sharing my journey. Sophia Lyon Fahs Papers, Sophia Lyon Fahs

Papers, Andover-Harvard Theological Library, Harvard Divinity School.

Farley, Edward. 1982. Ecclesial reflection: An anatomy of theological method. Philadelphia: Fortress Press.

Gudmundson, Emil. 1956. The theology implicit in the writings of Mrs. Sophia Lyon

Fahs. Sophia Lyon Fahs Papers, Andover-Newton Theological Library, Harvard Divinity School.

Hunter Edith. 1966a. Sophia Lyon Fahs: A biography. Boston: Beacon Press. . 1966b. The audacious mind of Sophia Lyon Fahs. The Register-Leader

(Jan.): 8-10.

Hutchinson, William R. 1992. The modernist impulse in American Protestantism.

Durham, NC: Duke University Press. 
Marsden, George M. 1991. Understanding fundamentalism and evangelicalism. Grand Rapids, Michigan: William B. Eerdmans Publishing.

MacLean, Angus H. 1960. The theological dilemma in religious education. Religious Education 55 (Jan./Dec.): 163-169.

Parke, David. 1965. The historical and religious antecedents of the New Beacon Series in religious education. Ph.D. diss., Boston University.

Proceedings of the first annual convention. 1903. The Religious education Association. Chicago, February 10-12.

Ranck, Shirley. 1976. $100^{\text {th }}$ birthday celebration for Sophia Lyon Fahs. Religious Education 71 (Nov./Dec.): 603-609. 1990. A feminist look at the theology of Sophia Fahs. Liberal Religious Education 5 (Fall): 27-41.

Sawicki, Marianne.1988. Historical methods and religious education. Religious Education 82 (Summer): 375-389.

Schmidt, Stephen A. 1983. A history of the religious education association. Birmingham, Alabama: Religious Education Press.

Timmins, Lois Fahs. n.d. The longest Sunday school lesson. The Sophia Lyon Fahs Collection. Meadville/Lombard Theological School, Hyde Park, Illinois.

Tracy, David. 1976/1996. Blessed rage for order: The new pluralism in theology. Chicago: The University of Chicago Press.

Wornom, Herman. n.d. Handbook of the Religious Education Association of the United States And Canada. 